\title{
The influence of personality types on the impulsive buying behavior of a consumer
}

\author{
Corina PELAU \\ The Bucharest University of Economic Studies, Bucharest, Romania \\ corina.pelau@fabiz.ase.ro \\ Daniela SERBAN \\ The Bucharest University of Economic Studies, Bucharest, Romania \\ danielaserban2011@gmail.com \\ Alexandra Catalina CHINIE \\ The Bucharest University of Economic Studies, Bucharest, Romania \\ alexandra.chinie@gmail.com
}

\begin{abstract}
The relation between the personality of consumers and their buying behavior has been a very much debated topic in the field of marketing researches. Several studies have shown that personality has a significant influence on the way consumer behave in their social and economic environment, in the way they approach and accept innovations and new developed products or even in their shopping behavior. This paper presents the influence of the Myers-Briggs personality dichotomies on the impulsive consumer behavior and the openness to buy newly launched products. Discriminant analysis was used to evaluate primary collected data and the core results show that extroverted, feeling-based decision-makers and perception oriented persons have more frequently an impulsive buying behavior at shopping sessions. Extroverts and intuition based consumers are more open to new products. The temptation to buy attractive unplanned products is higher for extroverts, feeling based decision makers and perceiving persons. Despite of this, none of the personality dichotomies influences the amount and care for spending in stores, this being influenced by other independent factors, mainly economic ones.
\end{abstract}

Keywords: consumer behavior, personality, impulsive behavior, innovative products, discriminant analysis.

\section{Introduction}

The topic of the relation between the personality of a person and its consumer behavior has been very much debated since the past century (Kassarjian, 1971; Raju, 1980; Foxall, Goldsmith, 1988; Albanese, 1993). Despite the fact that for a long time several studies have been done, the relation between a consumer's personality and its behavior can still give new insights in different specific topics and therefore several authors consider that it should be revitalized (Bosnjak, Bratko, et al., 2007; Solomon, Bamossy, et.al. 2010) and can still be useful for the management decisions of the producers.

For many years, researchers in the field of consumer behavior have tried to explain the buying decisions that consumers make. Depending on this behavior a company can adjust its marketing strategy and it can influence its decisions as a consequence to this analysis. Solomon mentioned that without understanding the way the consumer feels and thinks at the moment of the buying decision, it is impossible for a company to offer the desired products in the way the consumer wants. In recent years, this situation is amplified 
by the fact that the products which are bought do not represent anymore just a way to cover the consumers' needs, but they also describe the personality of the consumer and it defines its image and identity within the society. Consequently, the consumer buys the products not only to have, to own and to consume them, but also to construct a personal image, to express his/her personality and to consolidate his image in the society (Solomon, et.al. 2010, p. XIV).

\section{Literature review}

The influence of the personality of consumers is investigated both for general topics, such as the influence of the personality on a pro-environmental and an ecological responsible behavior (Balderjahn, 1988; Hirsh, Dolderman, 2007, Gunter, Furnham, 2014; Kvasova, 2015,) and for specific topics, such as the driving behaviour (Bone, Mowen, 2006), the preference for beauty treatments (Mowen, Longoria, et.al. 2009) or the outfit of the consumers, the clothes they are wearing (Popa, Pelau, 2016; Bratucu, et.al. 2017). From the technological to the social field, personality has a role in the way consumers approach new developments and recent trends. Technological innovations have determined researches to link the personality to the use of new IT and mobile applications (Yoo, Gretzel, 2011; Dinsmore, Swani, et.al. 2017). Besides this, technological developments in the field of neuroscience have raised the idea of investigating the relation between personality and brain structure (Krueger, Johnson, 2008; DeYoung, Hirsh, et.al. 2010). Different social aspects can also be explained by the personality of a person, such as the personalization of the advertising message (Haugtvedt, Petty, et.al. 1992; Moon, 2002; Pop et.al., 2009) or the relation to the extended social environment (Sun, Wu, 2012; Mitrut, et. al. 2013).

A special attention has been given to the analysis of the consumer's personality for retailers (Adjei, Clark, 2010; Dabija, et.al. 2014; Gohary, Hanzaee, 2014). Knowing the factors that determine consumers to buy can help retail companies to develop and adjust their strategies and instruments according to these and therefore increase the efficiency and the effectiveness of a shopping visit (Odekerken-Schröder, De Wulf, et.al. 2003; Egan, Taylor, 2010; Pop, Pelau, 2011). Several researches show the influence of personality traits on the behavior of the consumer due to the fact that the efficiency of the companies depend upon the decision of the consumers for several product categories. Extroversion, neuroticism, conscientiousness and openness to new experiences have a positive influence on the purchase intention of global brands (Zabkar et al., 2017). This research proves that the personality traits influence the associations related to global brands, the price sensitivity and the country bias, factors that affect the purchasing intention of the consumers. The personality also plays an important role in the relationship between a consumer goods company and its customers. Adjei and Clark (2010) show in their research that certain personality traits have an impact on the satisfaction of consumers and on the relationship quality. Traits like the consumer's tendency to innovativeness and the variety seeking behavior influence the loyalty towards certain brands (Adjei, Clark, 2010). Gohary and Hanzaee (2014) show in their study that personality traits like conscientiousness, neuroticism and openness have an influence on the impulsive and utilitarian shopping behavior.

This research is pointing out the analysis of the influence of the Myers-Briggs personality dichotomies on the impulsive buying behavior and the openness to buy newly 
launched products. The Myers-Briggs Type Indicator consists of the following four dichotomies which define the personality of people: extroversion-introversion dichotomy, which is referring to the focus of the person mainly on the outer or mainly on the inner world, sensing-intuition dichotomy that takes in consideration the way information about products is worked out, thinking-feeling dichotomy, which is referring to the way people make their buying decisions, and the judging-perceiving dichotomy, which is referring to the planning or spontaneity of buying activities (Furnham, 1996; Myers \& Briggs Foundation, 2017). Also the research tested if certain personality types are predisposed to impulsive behavior towards newly launched products or to the openness to buy new products.

\section{Methodology of research}

The objective of this research is mainly to determine and characterize the relationship between the personality of a person and certain types of his or her consumer's behavior. For this objective, a questionnaire was developed, in which both the personality of a person and also certain characteristics of the person treated as a consumer were tested. The Meyer Briggs dichotomies were used for the determination of the personality of the respondents, asking a set of three questions for each of them. In order to determine the features of the consumer behavior, Likert scale questions were used, the scale from 1 to 5 , the value of 5 was assigned for the total agreement and the value 1 for the total disagreement of the respondents. The survey was carried out during the period November-December 2016, in the urban population and 207 valid questionnaires were obtained.

During the first stage of the analysis, the personality types of the respondents were determined based on the answers for the Meyer Briggs dichotomies, producing the profile of the respondents. Therefore, the following results were obtained for personality types in the sample of consumers: 112 (54.1\%) extroverts, 95 (45.8\%) introverts, 95 (45.8\%) intuition based persons and 112 (54.1\%) sensing based persons, 126 (60.8\%) thinking decision makers and $81(39.1 \%)$ feeling based decision makers, $104(50.2 \%)$ judgers of the outside world and 103 (49.7\%) perceivers.

In order to determine if there is a specific buying behavior for each of the personality types, the discriminant analysis was applied. The indicators of the discriminant analysis were calculated using the SPSS software for each of the four dichotomies related to five types of impulsive behaviors and outputs were presented. In order to determine the relevance of the differences in the buying behavior, the means and the difference between the means for each personality group, Wilk's Lambda, the F-test, the t-test and their significance $\mathrm{p}(1,205)$ as the computed probability to commit the type one error have been calculated and interpreted (Backhaus, Erichson et.al 2000).

\section{Results and discussions}

The results of the analysis are presented in Table 1, consisting in the determination of personality characteristics of the consumer and his or her observed impulsive buying behavior.

The influence over the buying behavior has been tested for five types of consumers according to their behaviors: consumers open to new products (Q1), consumers buying only or mostly already known products (Q2), the buyer which is tempted by newly 
launched products (impulsive behavior) (Q3), consumers buying only planned products (Q4) and one question regarding the value of the spending, more precisely, the researchers were concerned if the consumers take care of the amount which is spent at a shopping session (Q5). It can also be easily observed that the statements Q1 and Q2 are somehow in an opposite position and the same happens with statements Q3 and Q4.

As it can be observed, the personality characteristics have the highest influence on the impulsive, temptation based behavior, as per Table 1. The dichotomy thinking-feeling, characterizing the decision making of the person has the most significant influence on this type of behavior $\left(\mathrm{F}_{\mathrm{TF} 3}=9.066, \mathrm{p}_{(1,205)}=0.003\right)$. The consumer who make their decisions based on first impressions ( $\mathrm{M}_{\text {Feeling3 }}=3.53$ ) are more likely to base their buying decision on their instincts, in comparison to the consumers who make their decisions based on logical arguments and rationalizing $\left(\mathrm{M}_{\text {Thinking3 }}=3.03\right)$. The dichotomy extroversion-introversion $\left(\mathrm{F}_{\mathrm{EI} 3}=7.818, \mathrm{p}_{(1,205)}=0.006\right)$ has another important influence on the buying behaviour. In this respect, extroverted persons $\left(\mathrm{M}_{\text {Extroversion3 }}=3.43\right.$ ) are more likely to base their buying decision on activating temptation compared to the introverted persons $\left(\mathrm{M}_{\text {Introversion3 }}=2.98\right)$. The overall perception of the outside world, characterized by the dichotomy judgingperceiving also has a significant role on the impulsive buying behaviour $\left(\mathrm{F}_{\mathrm{JP3}}=4.217, \mathrm{p}\right.$ $(1,205)=0.041<5 \%)$. People who define their relation with the world based on perceptions (MPerceiving3 $=3.39$ ) are more often activated as consumers by products than people who judge the outside world $\left(M_{\text {Judging3 }}=3.06\right)$.

For the opposite behavior "buying only planned products" (Q4), the dichotomy extroversion-introversion has the highest influence $\left(\mathrm{F}_{\mathrm{EI} 4}=2.953, \mathrm{p}_{(1,205)}=0.087<9 \%\right)$, but it exceeds the relevant $\mathrm{p}$-value of $5 \%$. In this case introverted people $\left(\mathrm{M}_{\text {Introversion4 }}=3.04\right)$ tend to have this type of behavior more frequent in comparison to extroverted people $\left(\mathrm{M}_{\text {Extroversion } 4}=2.74\right)$ in $91 \%$ of cases.

For the behavior characterized by openness of buying newly launched products, it can be observed that the dichotomies intuition-sensing and extroversion-introversion have a significant influence. People who base their general decision on simple information, also referred to as intuition, are more open to new products $\left(M_{\text {intuiton1 }}=3.82\right)$ than people who make more judgmental interpretations of the information they gather $\left(\mathrm{M}_{\text {Sensing1 }}=3.25\right)$. The influence of the dichotomy intuition-sensing on the behaviour characterized by openness for new products, is the highest, having $\mathrm{F}_{\mathrm{IS} 1}=13.034$ and $\mathrm{p}_{(1,205)}=0.000$. Another dichotomy, which has a significant influence on the behaviour "open to new products" is extroversion-introversion $\left(\mathrm{F}_{\mathrm{EI} 1}=8.149, \mathrm{p}_{(1,205)}=0.005<1 \%\right)$. In this case extroverted consumers $\left(\mathrm{M}_{\text {Extroversion1 }}=3.72\right)$ are more open to new products than introverted persons $\left(\mathrm{M}_{\text {Introversion1 }}=3.27\right)$.

As expected, this influence is also reflected in the opposite behavior "buying known products". For this type of behavior, the most significant influence factor is represented by the dichotomy intuition-sensing $\left(\mathrm{F}_{\text {IS2 }}=9.332, \mathrm{p}_{(1,205)}=0.003\right)$. In this case, the people characterized by the need of interpreting the information they gather, labelled "sensing" in this model $\left(\mathrm{M}_{\text {Sensing2 }}=3.89\right)$ rather buy the products they know, in opposition to people who are intuitive in information seeking $\left(\mathrm{M}_{\text {Intuition2 }}=3.47\right)$. 
Table 1. Influence of the personality on the impulsive buying behaviour

\begin{tabular}{|c|c|c|c|c|c|c|c|}
\hline Items & $\begin{array}{l}\text { Personality } \\
\text { traits }\end{array}$ & Mean & F value & $\begin{array}{l}\text { Wilk' } \\
\text { Lambda }\end{array}$ & $\begin{array}{l}\operatorname{Sig}(p) \\
\text { df: } \quad 1 \text {, } \\
205\end{array}$ & t-test & $\begin{array}{l}\text { Mean } \\
\text { Difference }\end{array}$ \\
\hline \multirow{8}{*}{$\begin{array}{lr}\text { Q1 - } & \text { Open } \\
\text { to } & \text { new } \\
\text { products }\end{array}$} & Extroverted & 3.72 & \multirow{2}{*}{8.149} & \multirow{2}{*}{0.962} & \multirow{2}{*}{0.005} & \multirow{2}{*}{2.855} & \multirow{2}{*}{0.44} \\
\hline & Introverted & 3.27 & & & & & \\
\hline & Intuition & 3.82 & \multirow{2}{*}{13.034} & \multirow{2}{*}{0.940} & \multirow{2}{*}{0.000} & \multirow{2}{*}{3.610} & \multirow{2}{*}{0.56} \\
\hline & Sensing & 3.25 & & & & & \\
\hline & Thinking & 3.44 & \multirow{2}{*}{1.284} & \multirow{2}{*}{0.958} & \multirow{2}{*}{0.259} & \multirow{2}{*}{-1.133} & \multirow{2}{*}{-0.18} \\
\hline & Feeling & 3.62 & & & & & \\
\hline & Judging & 3.44 & \multirow{2}{*}{0.881} & \multirow{2}{*}{0.996} & \multirow{2}{*}{0.349} & \multirow{2}{*}{-0.939} & \multirow{2}{*}{-0.14} \\
\hline & Perceiving & 3.59 & & & & & \\
\hline \multirow{8}{*}{$\begin{array}{l}\text { Q2 - buying } \\
\text { known } \\
\text { products }\end{array}$} & Extroverted & 3.59 & \multirow{2}{*}{2.554} & \multirow{2}{*}{0.988} & \multirow{2}{*}{0.112} & -1598 & -022 \\
\hline & Introverted & 3.82 & & & & -1.590 & -0.22 \\
\hline & Intuition & 3.47 & 9332 & 0956 & 0.003 & -0.419 & -0.41 \\
\hline & Sensing & 3.89 & 9.332 & 0.956 & 0.003 & & -0.41 \\
\hline & Thinking & 3.75 & 0914 & 0.996 & 0340 & 0956 & 013 \\
\hline & Feeling & 3.61 & 0.914 & 0.996 & 0.340 & 0.956 & \\
\hline & Judging & 3.77 & 1276 & 0993 & 0260 & 1130 & 015 \\
\hline & Perceiving & 3.62 & $1.2 / 6$ & 0.993 & 0.260 & 1.130 & 0.15 \\
\hline Q3 - buyer & Extroverted & 3.43 & 7818 & 0962 & 0006 & 2796 & 044 \\
\hline is tempted & Introverted & 2.98 & 1.010 & 0.703 & 0.000 & 2.170 & 0.44 \\
\hline by new & Intuition & 3.27 & 0224 & 0999 & 0636 & 0473 & 007 \\
\hline & Sensing & 3.19 & $0.2 \angle 4$ & 0.999 & 0.636 & $0.4 / 3$ & 0.07 \\
\hline & Thinking & 3.03 & 0066 & 0958 & 0003 & -3011 & -049 \\
\hline & Feeling & 3.53 & 9.066 & 0.958 & 0.003 & -3.011 & -0.49 \\
\hline & Judging & 3.06 & 4217 & 0980 & 0041 & 2054 & 033 \\
\hline & Perceiving & 3.39 & 4.217 & 0.980 & 0.041 & -2.054 & -0.33 \\
\hline Q4 - buying & Extroverted & 2.74 & 2.953 & 0.986 & 0.087 & -1.719 & -0.30 \\
\hline only & Introverted & 3.04 & 2.953 & 0.986 & 0.087 & -1.119 & -0.30 \\
\hline planned & Intuition & 2.73 & 2240 & 0989 & 0135 & 1500 & 026 \\
\hline products & Sensing & 3.00 & 2.249 & 0.989 & 0.135 & -1.500 & $-0 . \angle 0$ \\
\hline & Thinking & 2.91 & 0.226 & 0.999 & 0.635 & 0.475 & 0.08 \\
\hline & Feeling & 2.82 & $0.2 \angle 6$ & 0.999 & 0.635 & & \\
\hline & Judging & 2.98 & 1356 & 0993 & 0246 & 1164 & מב ח \\
\hline & Perceiving & 2.77 & 1.356 & 0.993 & 0.246 & 1.104 & 0.20 \\
\hline Q5 - buyer & Extroverted & 3.20 & 0822 & 0996 & 0.366 & -0.907 & -0.15 \\
\hline takes care & Introverted & 3.35 & & & & & \\
\hline of how & Intuition & 3.24 & 0.133 & 0.999 & 0.716 & -0.365 & -0.06 \\
\hline he/she is & $\begin{array}{l}\text { Seninging } \\
\text { Thinking }\end{array}$ & $\frac{3.30}{3.26}$ & & & & & \\
\hline spending & Feeling & 3.28 & 0.007 & 1.000 & 0.935 & -0.082 & -0.01 \\
\hline & Judging & 3.21 & 0.585 & 0.997 & 0.445 & -0765 & -0.12 \\
\hline & Perceiving & 3.33 & 0.503 & וצים & 0.445 & -0.103 & -0.12 \\
\hline
\end{tabular}

Source: Authors' own research.

For the behavior regarding the value of spending there is no significant influence from the personality type of the consumers (all $p>0.37$ ), as probably all types of consumer take care of how much they spend and they have limited resources. This is a behavior that is probably determined by the budget of the consumer. 


\section{Conclusion}

Taking into consideration the fact that nowadays companies have achieved, through different customer relationship management programs, an increased possibility of connecting the shopping behaviour of a consumer to its identity and therefore to its personality, the topic of relating personality and consumer behaviour represents a top research topic of higher actuality than ever. It is known that the personality of its consumers can determine companies to adjust their strategies according to the typology and sensitiveness of the consumer category. Moreover, individualized communication means are allowing companies nowadays to segment advertising campaigns according to the typology and consequently to the personality of a consumer.

Regarding the impulsive buying behaviour, the results of the research show that personality traits like extroversion, feeling based decision making and a mind structure based on perceptions have a significant role in the activation of the impulsive buying behaviour. The focus of the extroverted persons on the outside world is also reflected in their willingness to buy new products and by an easier temptation toward new products. Introverts, on the other hand, are more reluctant to buy new products and for them new products are less tempting. Buying new products is also a thing of intuition, consequently consumers who work out the information about the outer world in an intuitive manner also have the tendency to buy new products based on a temptation. The probability of buying tempting products is higher for consumers who make their decisions based on feelings. This type of consumers do not analyze too much, in depth, if to buy a product or not and consequently if they like a certain product they just buy it.

The interesting result is that the opposite behavior of "buying only planned products" is influenced in a significant way only by the trait introversion. Consumers having this type of personality are interacting less with the outer world and therefore they are less attentive to newly launched products. Consequently more of them buy only the products they have planned, previously to the shopping session. Consumers with a sensing way of working information out have also the tendency to buy only known products. In comparison to this relation, the openness to buy new products is more frequent among consumers with an extroverted, intuition based behavior. The opposite behavior of buying only known products is significantly influenced by the personality type "sensing", also showing a weaker relationship to personality.

Taking all these core results into consideration, it can be stated that there are types of consumer behaviours that are more related to personality than others, at different levels of associations. Consequently, it is important to determine those buying behaviours and personality characteristics that are highly correlated and use this data to design the marketing-mix tools. Communication and advertising are some of the instruments which should be adapted depending on the personality of the main type of consumers. For instance new products and emotional product groups should be rather offered to extroverted, intuition based consumers as the probability to develop a purchase intention among these consumers is higher and as a consequence the marketing mix should be adapted and focused on this group. On the other hand, to introverted, sensing based consumers, a company should offer rather known products. Another aspect is the design of the advertising materials. Extroverted, intuition based consumers will rather be attracted by advertising materials which should reflect their personality, containing emotional 
images. On the other hand sensing oriented consumers will prefer in depth informative advertising.

\section{References}

Adjei, M.T.; Clark, M.N. (2010). Relationship marketing in a B2C context: The moderating role of personality traits, Journal of Retailing and Consumer Services, 17(1), 73-79

Albanese, P.J. (1993). Personality and Consumer Behaviour: An Operational Approach, European Journal of Marketing, 27(8), 28-37

Backhaus, K.; Erichson, B.; Plinke, W.; Weiber, R. (2000). Multivariate Analysemethoden Eine anwendungsorientierte Einfuehrung, Springer, Berlin

Balderjahn, I. (1988). Personality variables and environmental attitudes as predictors of ecologically responsible consumption patterns, Journal of Business Research, 17(1), 51-56.

Bazzani, C.; Caputo, V.; Nayga, R.M.; Canavari, M. (2017). Revisiting consumers' valuation for local versus organic food using a non-hypothetical choice experiment: Does personality matter? Food Quality and Preference, 62, 2017, pg. 144-154.

Bone, S.A.; Mowen, J.C. (2006). Identifying the traits of aggressive and distracted drivers: a hierarchical trait model approach, Journal of Consumer Behavior, 5(5), 454-464

Bosnjak, M., Bratko, D., Galesic M., \& Tuten, T. (2007). Consumer personality and individual differences: Revitalizing a temporarily abandoned field, Journal of Business Research, 60 (6) (Special Issue: Consumer Personality and Individual Differences), 587-589.

Bratucu, G.; Epuran, G.; Gardan, D.A. (2017). The evolution of textile and clothing industry in Romania: an analysis from the perspective of imports and exports determinants, Industria Textila, 68(2), 147-155.

Dabija D.C., Pop N.Al., Szentesi S.G. (2014). A customer-oriented perspective on retail brand equity in the fashion Industry, Industria Textila, 65, 37-46.

Dabija, D. C.; Pop, N. Al.; Alt M. A.; Pelau, C. (2010): Consumers perception of retail formats diachronic research in Romania, in Bauer A., Agardi I., Conference Proceedings of the EMAC Regional Conference - Marketing Theory Challenges in Emerging Societies MTC4, Budapest, Hungary, September 24 - 25 2010, 374-380.

DeYoung, C. G., Hirsh, J. B., Shane, M. S., Papademetris, X., Rajeevan, N., \& Gray, J. R. (2010). Testing predictions from personality neuroscience: Brain structure and the big five. Psychological Science, 21, 820-828

Dinsmore, J.B.; Swani, K.; Dugan, R.G. (2017). To "Free" or Not to "Free": Trait Predictors of Mobile App Purchasing Tendencies, Psychology \& Marketing, 34(2), 227-244.

Dmitrovic, T.; Vida, I.; Reardon, J. (2009). Purchase behavior in favor of domestic products in the West Balkans, International Business Review, 18, 523-535.

D'Rozario, D. (1999): Effect of Assimilation on Prepurchase External Information-Search Tendencies, Journal of Consumer Psychology, 8(2), 187-209.

Egan, V.; Taylor, D. (2010). Shoplifting, unethical consumer behaviour, and personality, Personality and Individual Differences, 48(8), 878-883

Foxall, G.R.; Goldsmith, R.E. (1988). Personality and consumer research: Another look, Journal of the Market Research Society, 30(2), 111-125 
Furnham, A. (1996). The big five versus the big four: the relationship between the MyersBriggs Type Indicator (MBTI) and NEO-PI five factor model of personality, Personality and Individual Differences, 21(2), 303-307

Gohary, A.; Hanzaee, K.H. (2014). Personality Traits as Predictors of Shopping Motivations and Behaviors: A Canonical Correlation Analysis, Arab Economics and Business Journal, 9, 166-174

Gunter, B.; Furnham, A. (2014). Consumer Profiles (RLE Consumer Behaviour): An Introduction to Psychographics, Routledge, London, New York

Haugtvedt, C.P.; Petty, R.E.; Cacioppo, J.T. (1992). Need for Cognition and Advertising: Understanding the Role of Personality Variables in Consumer Behavior, Journal of Consumer Psychology, 1(3), 239-260

Hirsh, J. B., \& Dolderman, D. (2007). Personality predictors of consumerism and environmentalism: A preliminary study. Personality and Individual Differences, 43, 1583-1593.

Jimenez-Martin, S.; Ladrón-de-Guevara, A. (2007). Modeling consumption patterns in the attribute space: Theory and evidence of hybrid behavior, International Journal of Research in Marketing, 24, 242-253.

Jones, M.A.; Reynolds, K.E.; Weunc, S.; Beatty, S.E. (2003): The product-specific nature of impulse buying tendency, Journal of Business Research, 56, 505- 511.

Kroeber-Riel, W., Weinberg P. (2003). Konsumentenverhalten, Vahlen, München.

Kassarjian, H.H. (1971). Personality and Consumer Behavior: A Review, Journal of Marketing Research, vol. 8, no. 4 (Nov., 1971), pp. 409-418

Krueger, R. F., \& Johnson, W. (2008). Behavioral genetics and personality: A new look at the integration of nature and nurture. In O. P. John, R. W. Robins, \& L. A. Pervin (Eds.), Handbook of personality: Theory and research (pp. 287-310). New York: Guilford.

Kvasova, O. (2015). The Big Five personality traits as antecedents of eco-friendly tourist behaviour, Personality and Individual Differences 83 (2015) 111-116

Luchs, M.G.; Mooradian, T.A. (2012). Sex, Personality, and Sustainable Consumer Behaviour: Elucidating the Gender Effect, Journal of Consumer Policy, 35(1), 127-144.

Mitrut, C.; Serban, D.; Vasilache, S. (2013). Indicators of Social Trust In Romania - A Quantitative Analysis, Economic Computation And Economic Cybernetics Studies And Research, 47(1), 27-39.

Moon, Y. (2002). Personalization and personality: Some effects of customizing message style based on consumer personality. Journal of Consumer Psychology, 12, 313-325.

Mowen, J.C.; Longoria, A.; Sallee, A. (2009). Burning and cutting: Identifying the traits of individuals with an enduring propensity to tan and to undergo cosmetic surgery, Journal of Consumer Behavior, 8(5), 238-251

Myers \& Briggs Foundation (2017). MBTI Basics, online at: http://www.myersbriggs.org/ my-mbti-personality-type/mbti-basics/, Accessed on: 6.03.2017

Odekerken-Schröder, G.; De Wulf, K.; Schumacher, P. (2003). Strengthening outcomes of retailer-consumer relationships: The dual impact of relationship marketing tactics and consumer personality, Journal of Business Research, 56(3), 177-190.

Orth, U.R.; Limon, Y.; Rose, G. (2010). Store-evoked affect, personalities, and consumer emotional attachments to brands, Journal of Business Research, 63, 1202-1208.

Pop, N. Al.; Pelau, C. (2011). Cognitive and emotional reactions in the buying decision and their impact on the success of technological changes, in: Rusu, C.: Proceedings of the 
7th International Conference on Management of Technological Changes, Alexandroupolis, Greece, September 2011, pg. 193-196.

Pop N. Al., Vladoi A.D. (2009). The Marketer - A complex specialist, a man of concept, decision and action, Amfiteatru Economic, 11(25), 9-20.

Popa, A.; Pelau, C. (2016). Differences in the clothing brand perception depending on generation, Industria Textila, 4, 260-264.

PICBE | 759

Raju, P.S. (1980). Optimum Stimulation Level: Its Relationship to Personality, Demographics, and Exploratory Behavior, Journal of Consumer Research, 7(3), 272282.

Rook, D.W. (1987). The buying impulse, Journal of Consumer Research, 14, 189-199.

Solomon, M., Bamossy, G., Askegaard, S., Hogg, M.K. (2010). Consumer Behavior - A European Perspective, 4th edition, Prentice Hall, Financial Times, Harlow.

Stock, R.M. Hippel, E.; Gillert, N.L. (2016). Impacts of personality traits on consumer innovation success, Research Policy, 45, 757-769.

Sun, T.; Wu, G. (2012). Influence of personality traits on parasocial relationship with sports celebrities: A hierarchical approach, Journal of Consumer Behavior, 11(2), 136-146

Yangui, A.; Costa-Font, M.; Gil, J.M. (2016) The effect of personality traits on consumers' preferences for extra virgin olive oil, Food Quality and Preference, 51, pg. 27-38.

Yoo, K.H.; Gretzel, U. (2011). Influence of personality on travel-related consumer-generated media creation, Computers in Human Behavior, 27, 609-621.

Zabkar, V.; Arslanagic-Kalajdzic, M.; Diamantopoulos, A.; Florack, A. (2017): Brothers in blood, yet strangers to global brand purchase: A four-country study of the role of consumer personality, Journal of Business Research, 80, 228-235. 